Jurnal Ilmu Pengetahuan dan Pengembangan Masyarakat Islam

p-issn: 2085-8833, e-issn: 2797-6963| Vol. 15, No. 1, April, 2021, pp. $43-54$

http: http://ejournal.uin-suska.ac.id/index.php/Menara/index

\title{
Komunikasi Edukasi untuk Pencegahan Penularan Covid-19 dan Peningkatan Derajat Kesehatan Masyarakat di Kabupaten Serang Banten
}

\author{
Ail Muldi ${ }^{1}$, Damanhuri ${ }^{2}$, Ameliana Putri ${ }^{3}$ \\ 1,2,3 Universitas Sultan Ageng Tirtayasa \\ Email: ail.muldi@untirta.ac.id
}

\begin{abstract}
Abstrak
Lokasi Desa Sukalaba yang berada di daerah perbukitan dan jauh menyebabkan kurang mendapat perhatian dan pemantauan pemerintah daerah. Permasalahan utama masyarakat Sukalaba yaitu ancaman penyakit karena kurang pengetahuan dan kesadaran dalam menerapkan protokol kesehatan, sampah masyarakat yang tidak terkelola, dan banyaknya lalat di pemukiman akibat maraknya peternakan ayam. Fokus kegiatan pengabdian adalah aspek kesehatan masyarakat dan lingkungan. Kegiatan bertujuan menghasilkan perubahan perilaku masyarakat yang mengarah pada Pola Hidup Bersih dan Sehat (PHBS) untuk pencegahan penularan penyakit termasuk Covid-19, peningkatan kebersihan masyarakat, dan kesehatan lingkungan. Pendekatan yang diterapkan adalah pendekatan komunikasi dengan model Extended Parallel Process yang memfokuskan pada komponen pesan, persepsi, dan efikasi diri. Hasil kegiatan masyarakat meliputi komunikasi edukasi pencegahan penularan Covid-19, perencanaan pengelolaan sampah terpadu, dan penyuluhan door to door tentang penggunaan racun lalat. Kegiatan pengabdian lain yang menunjang yaitu senam sehat secara rutin, kerja bakti untuk kebersihan musala, dan penanaman 1.000 pohon.
\end{abstract}

Kata Kunci: komunikasi edukasi, Covid-19, kesehatan masyarakat

\begin{abstract}
Location of Sukalaba village located in the hilly area and far away which causing to lack of attention and monitoring by the regional government. The main problem of Sukalabans is disease threat because they are lack of knowledge and awareness in implementing health protocols and the garbage is not managed causing lots of flies around the settlement as a result of the large number of chicken farms. Focus of these service activities are public health and environment aspect. These activities aimed to change community behavior which led to a clean and healthy lifestyle (PHBS) to prevent disease transmission including covid-19, increase community hygiene and environmental health. The applied approach is communication approach with Extended Parallel Process model which focused to components of message, perception, and self-efficacy. The results of community activities covered educational communication of preventing of Covid-19 transmission, integrated waste management planning, and door-to-door counseling about use of fly poison. Other supporting activities are healthy exercise regularly, community service to mosque cleanliness, and planting 1000 trees.
\end{abstract}

Keywords: Educational communication, Covid-19, public health

\section{Pendahuluan}

Desa Sukalaba memiliki luas wilayah dengan total area sekitar 200 ha. Setara dengan 6,79 persen luas wilayah di Kecamatan Gunung Sari merupakan desa dengan 
luas wilayah terkecil di Kecamatan Gunung Sari, Kabupaten Serang secara umum. Kecamatan Gunung Sari berdasarkan indikator kependudukan kabupaten merupakan kecamatan dengan jumlah penduduk paling sedikit yaitu 20.813 jiwa dan kecamatan yang paling jarang penduduknya yaitu hanya 428 jiwa per kilometer persegi. Hal ini terjadi karena wilayah Kecamatan Gunung Sari merupakan wilayah dataran tinggi/ perbukitan (BPS Kabupaten Serang 2020a).

Begitu pun, wilayah Desa Sukalaba berada di dataran tinggi Kabupaten Serang sehingga lahannya banyak digunakan untuk ladang/ tegalan, pertanian, dan perkebunan. Status pemerintahan Desa Sukalaba adalah desa yang terdiri dari 6 dusun, 2 Rukun Warga (RW) dan 9 Rukun Tetangga (RT) dengan jumlah penduduk 2.253 jiwa di tahun 2019. Fasilitas kesehatannya relatif masih minim karena hanya memiliki 1 tempat praktik bidan desa sedangkan rumah ibadah dari 2 RW memiliki 5 musala/ masjid cenderung cukup banyak (BPS Kabupaten Serang 2020b). Kebanyakan masyarakat Sukalaba memiliki mata pencaharian sebagai petani dan buruh. Hal ini selaras dengan wilayah Kabupaten Serang sebagai wilayah pertanian dan industri.

Berdasarkan pengamatan dan dialog dengan pihak Pemerintah Desa Sukalaba dan masyarakat diketahui permasalahan Desa Sukalaba yang lebih mengancam saat itu adalah aspek kesehatan masyarakat. Pandemi Covid-19 telah melanda seluruh dunia khususnya Indonesia setelah ditemukannya warga Indonesia yang menjadi kasus pertama Covid-19 per Maret 2020. Demikian, titik tolak awal Covid-19 menjadi pandemi di Indonesia. Keputusan Presiden 12 tahun 2020 yang terbit pada April 2020 menetapkan pandemi Covid-19 sebagai bencana nasional.

Belakangan, Indonesia dan semua pemerintah daerah berupaya mencegah penularan Covid-19 dengan kampanye penerapan protokol kesehatan. Pandemi Covid19 berdampak kepada penerapan sekolah secara daring. Anak-anak Desa Sukalaba pun terimbas kebijakan ini. Penerapan sekolah daring di Kabupaten Serang terkendala infrastruktur pendidikan yang belum memadai dan kesulitan orang tua dalam pendampingan belajar anak. Riset Nasir dan Sudirman (2021) menemukan bahwa orang tua mengalami kesulitan dalam membimbing belajar anak secara daring pada masa pandemi Covid-19, meliputi: (1) anak sering menatap telepon seluler; (2) pengeluaran orang tua bertambah untuk membeli paket data; (3) pembelajaran menjadi kurang efektif; dan (4) keluarga kesulitan mengontrol anaknya.

Kendati pemerintah menetapkan Covid-19 sebagai bencana nasional tetapi kondisi ini belum diketahui dan dipahami masyarakat Desa Sukalaba dengan baik. Terlihat secara kasat mata masyarakat Sukalaba masih belum memiliki kesadaran untuk menerapkan protokol kesehatan dan melaksanakan kebijakan pencegahan pandemi Covid-19. Bahkan sebagian masyarakat abai karena kurang informasi tentang Pandemi Covid-19. Sehingga hal ini sangat berbahaya bagi masyarakat khususnya kelompok usia tua yang rentan terinfeksi Covid-19.

Pemerintah membuat berbagai kebijakan tentang pandemi Covid-19 yang bertujuan untuk pencegahan penularannya semakin meluas meliputi: (1) berdiam diri di 
rumah (Stay at Home); (2) pembatasan sosial (Social Distancing); (3) pembatasan fisik (Physical Distancing); (4) penggunaan masker; (5) kebersihan diri (cuci tangan); (6) bekerja/belajar di rumah (Work From Home/Study From Home); (7) menunda kegiatan yang melibatkan orang banyak; (8) pembatasan sosial berskala besar (PSBB); dan (9) pemberlakuan masa normal baru (Tuwu 2020).

Tingkat pengetahuan masyarakat tentang Covid-19 erat hubungannya dengan perilaku pencegahan penularan Covid-19 menurut Purnamasari dan Raharyani (2020). Ditemukan bahwa tingkat pengetahuan tentang Covid-19 didukung dengan tingkat pendidikan yang tinggi karena aksesibilitasnya dalam mendapatkan informasi dan memahami permasalahan (Yanti et al. 2020). Pengetahuan yang memadai tentang Covid-19 simultan dengan penerimaan informasi di masyarakat (Sulistyaningtyas 2020).

Selain permasalahan Covid-19, masyarakat Sukalaba memiliki permasalahan kesehatan lain yang dianggap mengancam kesehatan masyarakat secara langsung yaitu ancaman banyaknya lalat yang berseliweran di rumah mereka akibat maraknya peternakan ayam dan sampah yang berserakan karena kurang terkelola dengan baik. Masyarakat Desa Sukalaba terganggu dengan keberadaan peternakan ayam yang hampir ada di setiap dusun/ kampung. Banyaknya jumlah ayam ternak dan kandang di setiap dusun/ kampung mengundang banyak lalat berdatangan dalam jumlah besar dan mengganggu kesehatan masyarakat.

Masyarakat Desa Sukalaba belum memiliki Tempat Pembuangan Sementara (TPS) bahkan diketahui banyak rumah masyarakat yang tidak memiliki tempat sampah. Akibatnya banyak sampah-sampah rumah tangga berada di pinggir jalan, di kebun bahkan di depan/belakang rumah masyarakat dalam kondisi berserakan. Bila musim hujan datang maka masyarakat Desa Sukalaba banyak yang terjangkit penyakit salah satunya membahayakan jiwa yaitu demam berdarah. Banyaknya penyakit yang menyerang masyarakat pada saat musim hujan diduga secara negatif oleh masyarakat berkaitan dengan persoalan kebersihan dan lingkungan.

Permasalahan kesehatan masyarakat Desa Sukalaba setali tiga uang dengan tuntutan untuk menerapkan pola hidup bersih dan sehat (PHBS). Masyarakat dengan usia tua tidak hanya rentan terhadap Covid-19 tetapi terhadap semua penyakit karena berkaitan dengan penerapan PHBS. Prihanti et al. (2018) menjelaskan bahwa usia berpengaruh signifikan terhadap perilaku PHBS. Selaras dengan Tauiq (2013) bahwa usia tua relatif kesulitan mendapatkan informasi, cenderung pasif, gampang terjangkit penyakit dan mengabaikan PHBS, dan sebaliknya dengan yang berusia muda

Berbeda dengan temuan Karuniawati dan Putrianti (2020), bahwa semakin tua usia akan semakin paham dan menerapkan PHBS. Lebih lanjut, aspek pendidikan berpengaruh terhadap penerapan PHBS, hal ini selaras dengan (Kusumawati et al. 2008). PHBS merupakan upaya menjaga kesehatan, dengan pencegahan dan perlindungan diri dari berbagai penyakit termasuk Covid-19. Penulis mengelompokkan bentuk PHBS dalam pencegahan penularan Covid-19 berdasarkan penelitian 
Karuniawati dan Putrianti (2020) meliputi: (1) mencuci tangan sebelum makan, setelah memegang uang dan setelah keluar rumah; (2) tidak berjabat tangan dengan orang lain; (3) menjaga kebersihan rumah dan barang-barang dengan cairan pembersih serta selalu membuka jendela dan ventilasi; (4) meminimalkan kegiatan di luar, menjaga jarak aman saat menghadiri kegiatan di luar rumah minimal dua meter dan menggunakan masker saat keluar rumah; (5) membiasakan keluarga hidup sehat, anggota keluarga tidak pernah lagi merokok secara tetap, menyediakan makanan sehat untuk keluarga, mencuci buah dan sayur, konsumsi air minimal 2 liter dan berolahraga minimal 30 menit sehari; (6) tidak melakukan perjalanan keluar kota.

Kegiatan pengabdian bertujuan kepada: (1) perubahan perilaku masyarakat yang taat dan disiplin pada penerapan protokol kesehatan untuk pencegahan penularan Covid-19; (2) perubahan perilaku masyarakat untuk menjaga kebersihan dan antisipasi wabah penyakit; dan (3) perubahan perilaku yang berorientasi peningkatan kesehatan diri dan kelompok serta lingkungan. Tujuan kegiatan berorientasi kepada perubahan perilaku yang mendorong pencapai pola hidup bersih dan sehat. Pendekatan komunikasi dilakukan karena dianggap tepat dalam menciptakan perubahan perilaku masyarakat.

Konsep komunikasi yang digunakan adalah strategi komunikasi perubahan perilaku (KPP) melalui model Extended Parallel Process (EPP). Model EPP menitikberatkan pada penggunaan pesan yang mendorong perasan terancam atas keberadaan Covid-19 dan efikasi diri atas ancaman tersebut. Jika perasaan terancam seseorang tidak tinggi maka orang tersebut tidak melihat pandemi sebagai hal penting dalam hidupnya. Sebaliknya jika merasa takut terhadap ancaman maka tidak akan berani melakukan inisiatif tindakan lebih jauh. Komunikasi yang mendorong perubahan perilaku atas Covid-19 dilakukan dengan meyakinkan orang bahwa hal ini bisa dikendalikan bila mengikuti perilaku yang telah disarankan. Komponen pesan yang mendorong perasaan terancam menjadi efektif dalam menurunkan penularan, mudah dipahami dan bisa dilakukan semua orang (Kementerian Kesehatan 2020).

Kegiatan pengabdian diharapkan bermanfaat untuk: (1) mencegah penularan Covid-19 yang semakin meluas di Kabupaten Serang khususnya di Kecamatan Gunung Sari; (2) meningkatkan derajat kesehatan masyarakat melalui pengelolaan sampah terpadu dan penanggulangan wabah penyakit akibat keberadaan peternakan ayam; (3) mendorong kebiasaan atau tindakan rutin masyarakat yang menunjang kesehatan masyarakat dan lingkungan. Manfaat kegiatan pengabdian masyarakat untuk jangka panjang diharapkan mendorong kemandirian masyarakat Desa Sukalaba dalam menjaga kesehatan dan kebersihan lingkungan.

\section{Metode}

Kegiatan pengabdian masyarakat dilakukan di Desa Sukalaba, Kecamatan Gunung Sari, Kabupaten Serang, Provinsi Banten. Pemilihan lokasi pengabdian di Desa Sukalaba 
karena lokasinya yang berada di daerah pegunungan dan jauh dari Kantor Pemerintahan Kabupaten Serang, sehingga diasumsikan tidak mendapatkan perhatian pemerintah daerah secara signifikan. Pelaksanaan program pengabdian kemitraan strategis dengan masyarakat Desa Sukalaba dilakukan selama tanggal 18 Januari sampai 13 Februari 2021, diketahui merupakan bulan-bulan pada masa pandemi Covid-19.

Pelaksanaan pengabdian di Desa Sukalaba terjadi di masa pandemi Covid-19 sehingga strategi pelaksanaannya secara teknis, dilakukan secara campuran yaitu luring dan daring. Kegiatan pengabdian secara luring dilakukan terjun secara langsung ke masyarakat Sukalaba dengan catatan kami yang terlibat di lapangan membawa surat tes Antigen dengan hasil positif dan dengan tetap memerhatikan protokol kesehatan. Sedangkan kegiatan pengabdian secara daring yaitu kegiatan komunikasi edukasi masyarakat berkaitan dengan pencegahan Covid-19 tentang penerapan protokol kesehatan melalui media video pada channel youtube dan instagram serta dapat di akses melalui scan code QR pada kanal KKM Sukalaba Official.

Pelaksanaan kegiatan komunikasi edukasi masyarakat untuk pencegahan penularan Covid-19 dan peningkatan derajat kesehatan masyarakat Desa Sukalaba yang berwawasan lingkungan dilakukan dalam dua bentuk yaitu program utama dan program pendukung pengabdian kepada masyarakat. Program utama sesuai tema pengabdian meliputi (1) Komunikasi edukasi pencegahan penularan Covid-19 kepada orang tua dan anak-anak; (2) Komunikasi perencanaan pengelolaan sampah terpadu bersama masyarakat; dan (3) Komunikasi penyuluhan door to door tentang penggunaan racun lalat. Pendekatan komunikasi dilakukan bertujuan untuk meningkatkan partisipasi masyarakat selaras dengan penelitian Suroso et al. (2014)

Program pendukung pengabdian dilakukan secara partisipasi melibatkan masyarakat untuk mengingatkan kembali pentingnya partisipasi warga secara individu dan kelompok dalam meningkatkan derajat kesehatan masyarakat. Program pendukung meliputi (1) Senam sehat secara rutin bersama masyarakat untuk meningkatkan kebugaran dan kesehatan; (2) Kerja bakti untuk membersihkan musala/masjid di 6 dusun dan potensi terjangkit Covid-19 karena tempat ibadah yang jumlahnya cukup banyak menjadi satu-satunya tempat berkumpul masyarakat dusun di Desa Sukalaba; (3) Penanaman 1.000 pohon di Desa Sukalaba untuk menanamkan kepedulian dan pelestarian lingkungan di tingkatan keluarga dan organisasi di tingkat desa dan di bawahnya. Kegiatan kemitraan pengabdian di Desa Sukalaba diilustrasikan Gambar 1. 


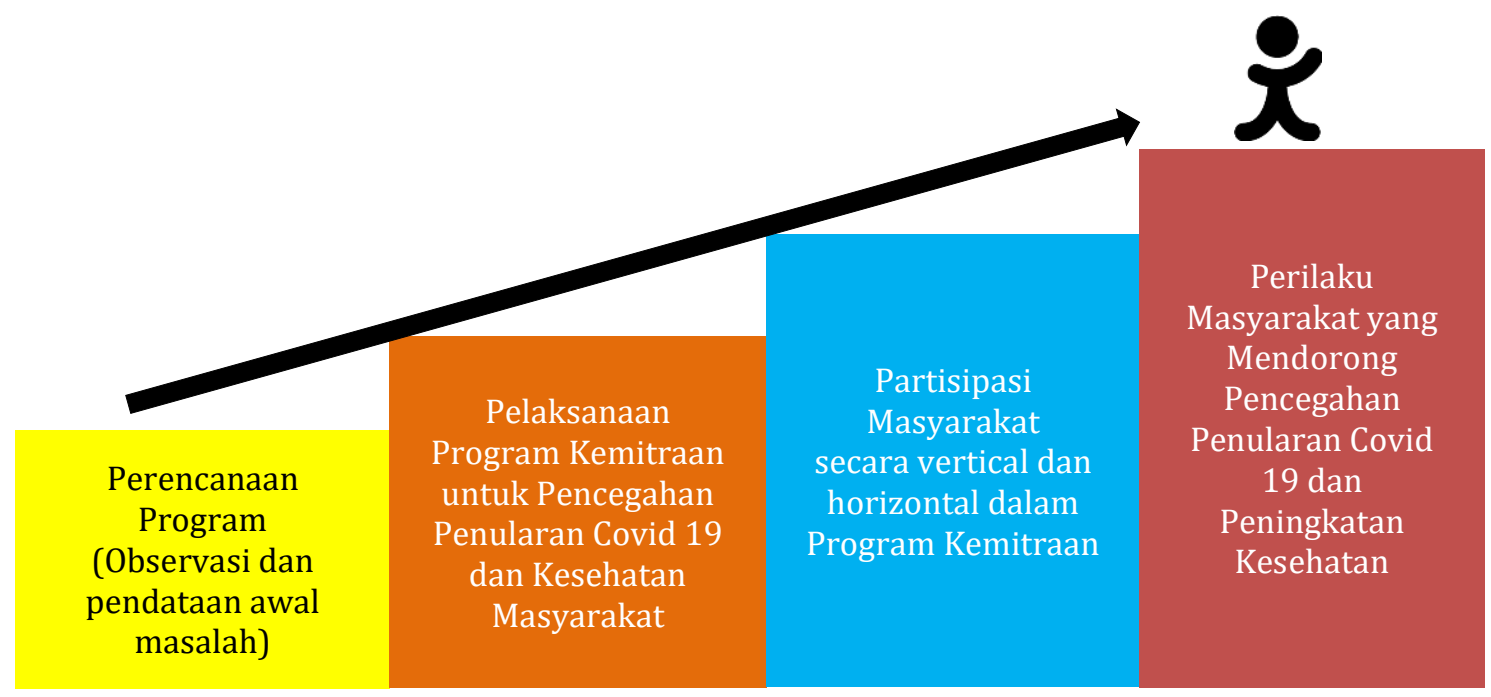

Gambar 1. Kerangka Kegiatan Pengabdian Masyarakat di Desa Sukalaba Kabupaten Serang

\section{Hasil dan Pembahasan}

Komunikasi edukasi tentang Covid-19 dilakukan secara tatap dan menggunakan media digital Youtube. Komunikasi edukasi Covid-19 menjelaskan secara langsung dan simulasi tentang penerapan protokol kesehatan dan pencegahan penularan infeksi Covid-19 di Desa Sukalaba. Kegiatan komunikasi edukasi dilanjutkan dengan fasilitasi pengadaan sabun dan tempat cuci tangan di lingkungan Desa Sukalaba, pembagian masker dan hand sanitizer serta penyemprotan disinfektan rutin seminggu sekali untuk pencegahan penyebaran Covid-19. Segmentasi khalayak penerima pesan edukasi masyarakat adalah kelompok orang tua, pemuda dan anak-anak.

Komunikasi edukasi Covid-19 kepada segmentasi masyarakat Desa Sukalaba secara antar pribadi (interpersonal) dengan media tatap muka dinilai lebih efektif dilakukan karena prosesnya terjadi secara dua arah (sirkuler) sehingga memungkinkan terjadi umpan balik dan dialog satu sama lain (Rakhmat, 2011). Model interaksi yang dilakukan dalam komunikasi edukasi masyarakat menghasilkan kesamaan persepsi pada kasus ini adalah pengetahuan tentang Covid-19 (Mulyana, 2017). Masyarakat pada awalnya cukup antusias dan semakin serius saat pesan banyak membahas tentang potensi ancaman jiwa bagi orang yang terjangkit Covid-19 sebagaimana dalam strategi komunikasi untuk perubahan perilaku dengan model Extended Parallel Process (EPP) yang disarankan Kementerian Kesehatan Republik Indonesia (2020). Model EPP relatif lebih tepat disampaikan kepada khalayak orang tua dari pada anak-anak dan pemuda.

Kebanyakan orang tua yang menjadi khalayak pesan edukasi Covid-19 memiliki tingkat pendidikan rendah yaitu di bawah wajib belajar belajar 12 tahun bahkan banyak juga yang tidak sampai tingkat Sekolah Menegah Pertama (SMP) atau sederajat. Kurangnya pengetahuan kelompok khalayak orang tua diakibatkan terbatasnya aksesibilitas sumber informasi dan ragam sumbernya. Akibatnya tidak menerapkan 
protokol kesehatan dan didukung juga minimnya fasilitas toko alat-alat kesehatan. Covid-19 lebih banyak diketahui dari perbincangan dengan orang lain meskipun relatif tidak banyak dan mendalam. Hal ini menguatkan padangan Tauiq (2013) bahwa kelompok masyarakat dari usia tua minim informasi kesehatan sehingga mengabaikan PHBS.

Aspek pendidikan yang rendah mendasari kurang pemahaman Covid-19 dan berimplikasi kepada penerapan protokol kesehatan sebagaimana diungkapkan Purnamasari dan Raharyani (2020), Yanti et al. (2020) dan Sulistyaningtyas (2020) berkaitan dengan penerimaan informasi dan tingkat pendidikan. Salah satu temuan yang belum diungkapkan dari literasi yaitu status sosial ekonomi menengah ke bawah diduga ikut berperan dalam akses dan penerimaan informasi secara luas dan beragam tentang Covid-19. Padahal kelompok usia tua secara kasus bersifat rentan dan merupakan kelompok usia dengan korban jiwa yang lebih banyak meninggal pada kasus terinfeksi Covid-19 di Indonesia. Artinya usia tua dengan tingkat pendidikan rendah dan status menengah ke bawah berpotensi pasif dan terbatas dalam akses dan penerimaan informasi yang berakibat pada perilaku yang tidak menerapkan protokol kesehatan. Kegiatan komunikasi edukasi masyarakat tentang Covid-19 lihat Gambar 2.

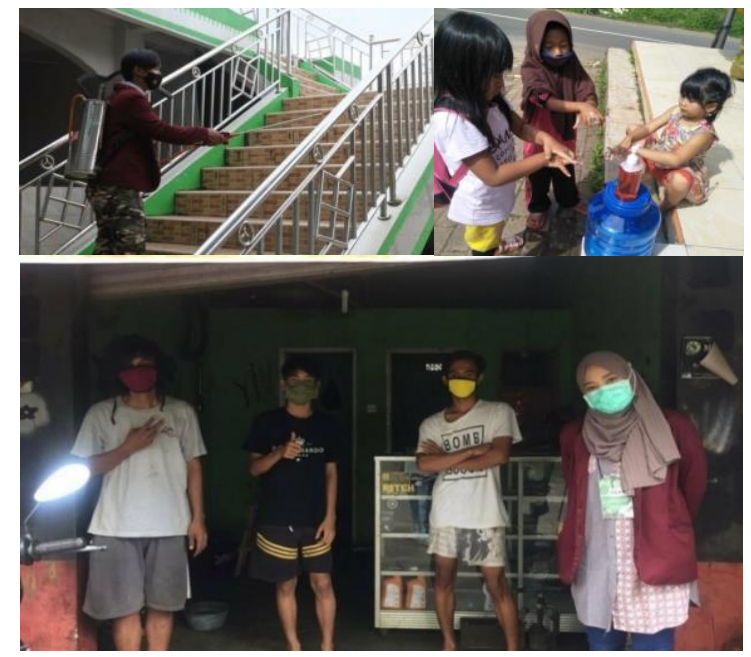

Gambar 2. Kegiatan Komunikasi Edukasi tentang Covid-19 kepada Masyarakat Sukalaba.

Komunikasi kemitraan masyarakat tentang bahaya Covid-19 yang dilakukan oleh Tim Pengabdi yang terhimpun dalam Kelompok 39 KKM Kemitraan Sultan Ageng Tirtayasa juga dilakukan melalu media digital youtube channel KKM Sukalaba Official. Kendati demikian kami membatasi akses informasi masyarakat Desa Sukalaba dalam mengakses informasi digital karena dampak negatif internet tentang Covid-19 salah satunya hoax yang berpotensi membingungkan masyarakat (Lestari et al. 2020). Video edukasi digital yang dibuat Tim Pengabdi diakses masyarakat melalui scan code $Q R$ yang sudah disebar melalui stiker barcode ke rumah-rumah masyarakat.

Pesan edukasi media digital berperan sebagai sumber informasi yang bisa diakses 
kapan saja melalui scan code $Q R$ yang telah diberikan. Disisi lain menjadi media peraga informasi digital tentang Covid-19 yang ditunjukkan sendiri oleh tim pengabdi kepada masyarakat khususnya orang tua dan anak-anak dengan simulasi. Pesan edukasi media digital bahsannya tentang seputar Covid-19, protokol kesehatan dan perilaku penunjang diri dalam pencegahan Covid-19. Banyak literatur penelitian komunikasi yang mengungkap konten video pada akun youtube berperan dalam penyebaran informasi secara luas dan massal. Kendati demikian, komunikasi antar pribadu lebih kuat dalam perubahan perilaku sebagaimana merupakan kekuatan komunikasi tatap muka yang diungkapkan DeVito (2011). Penjabaran pesan edukasi Covid-19 bisa lihat Tabel 1.

Tabel 1. Pesan Edukasi Media Digital tentang Covid-19

\begin{tabular}{cll}
\hline No & \multicolumn{1}{c}{ Pesan Edukasi Covid-19 } & \multicolumn{1}{c}{ Link Youtube Channel } \\
\hline 1 & Tips mengatur pola makan sehat di masa pandemi & https://youtu.be/Yct5mW13-Ow \\
\hline 2 & 6 langkah mencegah penyebaran Corona Virus & https://youtu.be/IOSMPOLBpBg \\
\hline 3 & Tips memilih masker yang cocok & https://youtu.be/In52OSB_y6o \\
\hline 4 & Tetap Sehat di Masa Pandemi & https://youtu.be/u0xQFzb-On4 \\
\hline 5 & Video Edukasi tentang Virus & https://youtu.be/RskQIihkd-k \\
\hline 6 & Cara Memakai Masker yang Benar) & https://youtu.be/YDhJ8eDFAFk \\
\hline 7 & Cara Mencuci Tangan berdasarkan Anjuran WHO & https://youtu.be/JIUIjC5gEhI \\
\hline 8 & Perlunya Rapid Test & https://youtu.be/T2MmZnP1Z7Q \\
\hline
\end{tabular}

Komunikasi edukasi Covid-19 mendorong perilaku pencegahan melalui pengadaan sarana pendukung protokol kesehatan dan penyemprotan disinfektan di ruang publik. Penyemprotan disinfektan di ruang publik mengikuti panduan penelitian Athena et al. (2020) menjelaskan bahwa potensi penularan infeksi Covid-19 banyak terjadi di area publik dan upaya disinfeksi dilakukan dengan penyemprotan disinfektan pada area publik tersebut. Di Desa Sukalaba tempat yang paling sering dijadikan tempat pertemuan banyak adalah musala/ masjid untuk kegiatan ibadah. Atas dasar hal tersebut tim pengabdi melakukan kegiatan penunjang dalam bentuk kerja bakti membersihkan musala/masjid di lima dusun di Desa Sukalaba supaya masyarakat tidak rentan tertular pada saat melakukan kegiatan ibadah di musala/ masjid.

Kegiatan penunjang lainnya adalah melakukan senam rutin untuk meningkatkan imun dan kesehatan masyarakat. Senam merupakan salah satu bentuk olah raga sehingga merupakan salah satu PHBS seperti diungkapkan Karuniawati dan Putrianti (2020). Bentuk-bentuk lain PHBS juga banyak diajarkan melalui konten edukasi media digital di Tabel 1. Kegiatan edukasi juga dilakukan untuk perencanaan pengelolaan sampah terpadu dan penyuluhan door to door untuk penggunaan racun lalat sebagai antisipasi untuk menghindari potensi penyakit yang diakibatkan banyaknya lalat yang berada di rumah-rumah masyarakat.

Kegiatan pengabdian yang dilakukan untuk mengantisipasi permasalahan sampah yang menumpuk dan berserakan di rumah dan ruang publik tim pengabdi berdiskusi dengan pemerintah desa dan kelompok pemuda (Gambar 3). Strategi komunikasi yang 
mendorong partisipasi peserta menghasilkan banyak gagasan tentang penanganan sampah. Dialog secara terbuka dengan para partisipan tentang isu pengelolaan sampah menghasilkan rencana pengelolaan sampah terpadu desa Sukalaba. Diketahui beberapa bulan berikutnya bahwa pengelolaan sampah terpadu Desa Sukalaba telah terkelola dengan baik atas peran Kelompok Karang Taruna. Pemerintah desa membuat tempat sampah untuk masing-masing rumah sehingga setiap keluarga membuang sampah di tempatnya. Kemudian setiap seminggu 1-2 kali sampah diangkut oleh Dinas Lingkungan Hidup Kota Serang untuk dibawa ke Tempat Pembuangan Umum di Taktakan Kota Serang. Setiap keluarga membayar iuran Rp. 20.000,00/bulan.
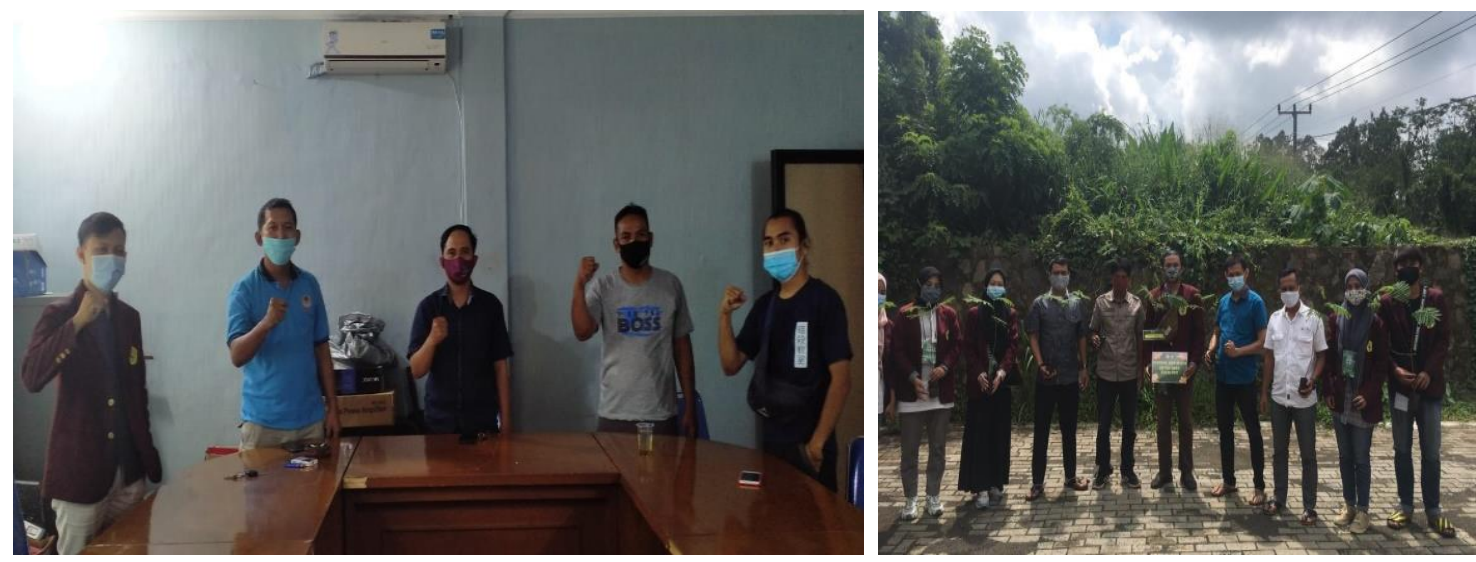

Gambar 3. Komunikasi Perencanaan Pengelolaan Sampah dan Penanaman 1.000 pohon.

Pendekatan komunikasi menurut Balliet (2010) berefek positif secara signifikan terhadap kerja sama di berbagai jenis dilema sosial. Komunikasi tentang penanggulangan sampah melahirkan kerja sama partisipan untuk menemukan solusi. Pengelolaan sampah secara terpadu Desa Sukalaba yang sekarang berhasil dilakukan merupakan hasil partisipasi beberapa pihak meliputi rumah tangga, kelompok pemuda, pemerintah desa dan pihak DLH Kota Serang. Keberhasilan program pembangunan (pemerintah desa) bergantung kepada partisipasi masyarakat (Stiglitz 2002: Singh dan Singh 2008). Keberhasilan pembangunan yang bertumpu pada partisipasi masyarakat karena terdapatnya umpan balik masyarakat dalam bentuk saran dan pendapat (Ummah et al. 2020). Karena partisipasi masyarakat memosisikan masyarakat sebagai aktor atau subyek pembangunan. Kegiatan pengabdian yang mendorong perencanaan sosial dan pengembangan masyarakat di tingkat lokal merupakan termasuk pengembangan masyarakat (Suharto, 2010).

Kegiatan pengabdian masyarakat di Desa Sukalaba dilakukan dalam bentuk penyuluhan door to door untuk menjelaskan tentang penggunaan racun lalat untuk menekan jumlah lalat yang terus berada di tempat tinggal masyarakat. Dari perspektif konseptual racun lalat merupakan inovasi untuk menekan bertambahnya jumlah lalat yang dihasilkan akibat banyaknya peternakan ayam di Desa Sukalaba. Pendekatan komunikasi dalam bentuk penyuluhan door to door membuat masyarakat khususnya ibu-ibu menjadi lebih cair dalam berinteraksi dan meningkatkan kepercayaannya untuk 
menggunakan racun lalat. Tampaknya benar yang diungkapkan Jalaludin Rakhmat (2011) bahwa komunikasi antar pribadi yang dilakukan dengan gembira dan menyenangkan sangat efektif mengubah perilaku karena hubungan kepercayaan yang mendasarinya.

Pendekatan partisipasi masyarakat juga dilakukan pada kegiatan penunjang pengabdian yaitu penanaman 1.000 pohon di ruang-ruang terbuka gundul di Desa Sukalaba dan partisipasi masyarakat untuk menanam pohon di rumahnya masingmasing, lihat Gambar 3. Kegiatan penanaman pohon secara sukarela dan partisipasi masyarakat merupakan bentuk kepedulian lingkungan. Hal ini perlu dilakukan mengingat banyaknya wilayah hutan yang dekat permukiman masyarakat mengalami penebangan liar. Penanaman pohon akan mendukung pelestarian lingkungan dan keseimbangan ekosistem alam yang bermanfaat untuk kesehatan ekosistem lingkungan dan masyarakat Desa Sukalaba. Hal ini selaras dengan ajaran Nabi Muhammad SAW bahwa Rasulullah bersabda "tidaklah seorang muslim menanam pohon kemudian di makan oleh burung, manusia atau binatang melainkan ia akan mendapat pahala sedekah (HR. Bukhori Muslim).

\section{Simpulan}

Kegiatan pengabdian memfokuskan kepada aspek kesehatan masyarakat dan lingkungan dengan pendekatan komunikasi edukasi masyarakat yang menitikberatkan pada perubahan persepsi dan kesadaran masyarakat dalam bingkai pola hidup bersih dan sehat. Komunikasi edukasi masyarakat dilakukan secara interaktif (linier) dan terbuka untuk mendorong partisipasi masyarakat berkaitan isu-isu persoalan strategis di Desa Sukalaba. Komunikasi edukasi masyarakat tentang kesehatan meliputi penerapan protokol kesehatan untuk pencegahan penularan infeksi Covid-19, komunikasi kelompok antara kelompok masyarakat dan pemerintah desa untuk perencanaan pengelolaan sampah terpadu dan komunikasi penyuluhan langsung secara door to door ke setiap rumah masyarakat.

Berdasarkan ragam komunikasi edukasi masyarakat dari tatap muka, media kelompok melalui diskusi, dan pemanfaatan media digital untuk edukasi masyarakat berbasis Youtube yang bisa diakses dari scan code $Q R$ diketahui memiliki pengaruh masing-masing dilihat dari pencapaian tujuan kegiatan pengabdian. Komunikasi edukasi masyarakat dengan media tatap muka memiliki kekuatan untuk mendorong perubahan perilaku masyarakat. Komunikasi edukasi masyarakat melalui diskusi mendorong tindakan kohesif kelompok dan terlihat mendorong kerja sama antar partisipan yang berpartisipasi.

Media edukasi digital berbasis Youtube cenderung lebih menarik tetapi sulit diakses oleh masyarakat khususnya kalangan kelompok usia tua yang rentan terjangkit penyakit. Kelompok usia tua relatif lebih sulit untuk akses dan menerima informasi tentang ancaman kesehatan dari pola hidup yang tidak bersih dan sehat, wabah 
penyakit dan risiko infeksi Covid-19. Temuan di lapangan menunjukkan hal ini diduga berkaitan dengan tingkat pendidikan dan status ekonomi masyarakat.

Komunikasi edukasi masyarakat bertujuan untuk menciptakan perubahan perilaku masyarakat yang mengarah kepada penerapan protokol kesehatan untuk pencegahan penularan penyakit termasuk Covid-19, peningkatan derajat kebersihan dan kesehatan lingkungan masyarakat Desa Sukalaba. Kegiatan program penunjang juga dilakukan untuk menciptakan daya dukung kesehatan dan lingkungan kepada masyarakat melalui kegiatan senam secara rutin, kerja bakti membersihkan musala/ masjid sebagai ruang publik yang banyak digunakan masyarakat dan penanaman pohon untuk pelestarian dan keberlanjutan lingkungan dan kehidupan masyarakat.

\section{Referensi}

Athena, Laelasari, E., Puspita, T. (2020). Pelaksanaan Disinfeksi dalam Pencegahan Penularan Covid dan Potensi Risiko Terhadap Kesehatan di Indonesia. Jurnal Ekologi Kesehatan, 19 (1), 1-20. DOI: https://doi.org/10.22435/jek.v19i1.3146.

Balliet, D. (2010). Communication and cooperation in social dilemmas: a meta- analytic review. J of Confl Resol. 54(39). Doi: 10.1177/0022002709352443.

BPS Serang [Badan Pusat Statistik]. (2020a). Kecamatan Gunung Sari dalam Angka 2020. Serang (ID): BPS Serang.

BPS Serang [Badan Pusat Statistik]. (2020b). Statistik Daerah Kabupaten Serang 2020. Serang (ID): BPS Serang.

Devito, J.A. (2011). Komunikasi Antar Manusia. Tangerang Selatan (ID): Karisma Publishing.

Karuniawati, B. \& Putrianti, B. (2020). Gambaran Perilaku Hidup Bersih dan Sehat dalam Pencegahan Penularan Covid-19. Jurnal Kesehatan Karya Husada, 8(2), 34-53.

Lestari et al. (2020). Komunikasi Risiko Covid-19 dan Persiapan Menghadapi New Normal pada Masyarakat Kelurahan Air Putih Kota Pekanbaru. Menara Riau, 14(2), 98-106. http://ejournal.uin-suska.ac.id/index.php/Menara/index

Mulyana, D. (2017). Ilmu Komunikasi Suatu Pengantar. Bandung (ID): Rosdakarya.

Nasir \& Sudirman. (2021). Mengungkap Kesulitan Keluarga dalam Membimbing Belajar di Masa Pandemi Covid-19: Exploratory Case Study. Gema Walodra 12(1), 51-59.

Prihanti, G.S. et al. (2018). Faktor-faktor yang Mempengaruhi Tingkat Perilaku Hidup Bersih dan Sehat pada Tatanan Rumah Tangga di Wilayah Puskesmas Poned X. Saintika Medika, 14(1), 7-14. https://doi.org/10.22219/sm.vol14.smumm1.6644.

Purnamasari, I., \& Raharyani, A. E. (2020). Tingkat pengetahuan dan perilaku masyarakat Kabupaten Wonosobo tentang Covid-19. Jurnal Ilmiah Kesehatan, 10(1), 33-42.

Rakhmat, J. (2011). Psikologi Komunikasi. Bandung (ID): Rosdakarya.

Singh, P. B. \& Singh, A. (2008). Impact and Effectiveness of Watershed Development Programmes in India. New Delhi: Centre For Rural Studies National Institute of 
Administrative Research Lal Bahadur Shastri National Academy Of Administration Mussoorie-248-179

Stiglitz, J.E. (2002). Partcipation and Development: Perspectives from the Comprehensive Development Paradigm. Review of Development Economics. 6 (2), 163-182.

Suharto, E. (2010). Membangun Masyarakat Memberdayakan Rakyat : Kajian Strategis Pembangunan Kesejahteraan Sosial dan Pekerjaan Sosial. Bandung (ID): Refika Aditama

Sulistyaningtyas, T., Jaelani J, Suryani, Y. (2020). Informasi Wabah Virus Covid-19. Bandung (ID): Institut Teknologi Bandung.

Tauiq, M., Nyorong, M., Riskiyani, S. (2013). Gambaran Perilaku Hidup Bersih dan Sehat Masyarakat di Kelurahan Parangloe Kecamatan Tamalanrea Kota Makassar. Diakses dari repository.unhas.ac.id

Tuwu, D. (2020). Kebijakan Pemerintah dalam Penanganan Pandemi Covid-19. Jurnal Publicuho, 3(2), 267-278. Doi:10.35817/jpu.v3i2.12535

Kemenkes RI [Kementerian Kesehatan Republik Indonesia]. (2020). Strategi Komunikasi Perubahan Perilaku dalam Pencegahan Covid-19. Jakarta (ID): Kemenkes RI

Kusumawati, Y., Astuti, D. \& Ambarwati. (2008). Hubungan antara Pendidikan dan Pengetahuan Kepala Keluarga tentang Kesehatan Lingkungan dengan Perilaku Hidup Bersih dan Sehat. Jurnal Kesehatan Masyarakat, 1(1), 47-56.

Suroso, H., Hakim, A., \& Noor, I. (2014). Faktor-faktor yang Mempengaruhi Partisipasi Masyarakat dalam Perencanaan Pembangunan di Desa Banjaran Kecamatan Driyorejo Kabupaten Gresik. Wacana 17(1), 7-15.

Yanti, et al. (2020). Community Knowledge, Attitudes, and Behavior Towards Social Distancing Policy as Prevention Transmission of Covid-19 in Indonesia. Jurnal Administrasi Kesehatan Indonesia, 8(1), 4-14. http://dx.doi.org/10.20473/jaki.v8i0.2020.4-14

Ummah SM, Muldi A, Winangsih R. 2020. Komunikasi Pembangunan Terintegrasi Kota Serang Berbasis Bale Sandi Maya. Jurnal Riset Komunikasi, 11(2), 107-130. http://dx.doi.org/10.31506/jrk.v11i2.10058 